Review

\title{
Organotin pollution in China: An overview of the current state and potential health risk
}

\author{
Dandan Cao $^{\mathrm{a}, \mathrm{b}}$, Guibin Jiang ${ }^{\mathrm{a}, *}$, Qunfang Zhou ${ }^{\mathrm{a}}$, Ruiqiang Yang ${ }^{\mathrm{a}}$

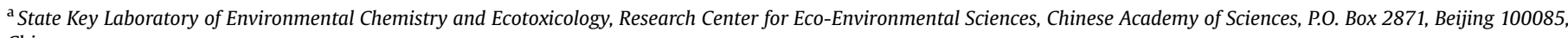 \\ China \\ ${ }^{\mathrm{b}}$ Environmental Science Division, School of Earth and Space Science, University of Science and Technology of China, Hefei, Anhui Province 230026, China
}

\section{A R T I C L E I N F O}

Article history:

Received 20 August 2007

Received in revised form 31 December 2007

Accepted 18 June 2008

Available online 30 October 2008

\section{Keywords:}

Organotin

China

Pollution

Impact

Monitoring

\begin{abstract}
A B S T R A C T
In recent years, considerable amounts of organotin compounds have entered the environment due to the wide industrial applications in China. Organotins were found in various environmental media. An overview of organotin contamination and distribution in China from various environmental samples, including waters and sediments, is presented to better understand the current state of organotin pollution in China and to improve environmental monitoring and management of organotin contamination. Exposure to organotin contaminated water and sediments induces accumulation of organotins in molluscs and biological effects such as imposex. Potential harmful effects on human health may also result from consumption of contaminated seafoods. Detailed information on distribution, impacts and assessment of risk to human health and marine ecosystems is discussed and monitoring of TBT using biomarkers is described. This review highlights the serious organotin contamination of coastal cities in China and emphasizes the need for long-term monitoring and the development of an effective regulatory program.
\end{abstract}

(c) 2008 Published by Elsevier Ltd.

\section{Introduction}

Except for methyltin possibly engendered by methylation during biological activities, organotin has been introduced into the environment exclusively through anthropogenic sources. For more than three decades, organotin compounds have been widely used in several industrial and agricultural applications such as slime inhibitors, mildew proofing agents, polyvinyl chloride stabilizers, and active biocides. Organotin, particularly, tributyltin (TBT), has extensively been used as a biocide agent in antifouling paints of ship hulls (Warren, 1973). To date, TBT is one of the most toxic chemicals that have been released into the marine environment by an anthropogenic source. The detection of BTs, including monobutyltin (MBT), dibutyltin (DBT), and tributylitn (TBT), in diverse ocean environmental media and biota indicate butyltin contamination of international aquatic systems (e.g. Fent, 1996; Takahashi et al., 1999; Tanabe, 1999; Zhou et al., 2001). TBT has also been observed to cause imposex phenomenon in some of the gastropods in America, Canada, Britain and France (Short and Sharp, 1989). Considering the adverse effects of organotin compounds, especially butyltin compounds, these chemicals have been placed on the black and grey lists of several international agreements and, since the late

\footnotetext{
* Corresponding author. Fax: +861062849371

E-mail address: gbjiang@rcees.ac.cn (G. Jiang).
}

1980s, have been banned from use in antifouling paints in many countries of Europe and North America (Chau et al., 1997). Recommendations have been made by the International Maritime Organization (IMO) to internationally prohibit the use of organotin compounds as biocides in antifouling paints by January, 2008 (Rüdel et al., 2003).

Despite global trends towards regulating organotins, only a few regions in Asia have related restrictions for these chemicals. The estimated organotin consumption in China is 7500 tons/year. The large use of butyltin compounds in various fields has caused widespread occurrence of water pollution in China (Jiang et al., 2001; Zhou et al., 2001). Unfortunately, except that Pesticide Ordinance prohibited the use of TBT paints on vessels less than $25 \mathrm{~m}$ in length and on fish cages in Hong Kong in 1992, no further restrictions on organotins have been implemented in China (Morton and Blackmore, 2001). With the growing demand for its usage in industry and agriculture within China, the presence of organotins in the environment and its deleterious effects are expected to increase.

Considering the organotin contamination problem in China along with the goals of the IMO, there is a critical need to comprehensively elucidate the present status of organotin contamination in China and to supply information to support future regulatory movements. This paper is aimed at reviewing the current distribution and impacts of organotins in China and summarizes monitoring efforts of organotins in marine environments in China. 
Studies have shown that organotin contamination generally occurs in the aquatic environment, mostly concentrated in coastal areas where water, sediments, and marine products have relatively high concentrations of butyltins (BTs). The high levels of organotin concentration in the coastal environments necessitate development of monitoring methods for organotin contamination. Marine monitoring efforts for organotin contamination of aquatic environments in China by and large have focused on studying the imposex phenomenon in gastropods caused by exposure to organotins.

\section{Distribution of organotins in environments of China}

\subsection{Distribution of organotins in marine and freshwater environments}

Presently in China, there is severe organotin contamination in marine and freshwater environments, especially offshore waters, port sites, and inner river dock yards. Compared to reported estimates of global TBT concentrations ranging from 1 to $1000 \mathrm{ng} / \mathrm{L}$ (Bryan and Gibbs, 1991), published TBT concentrations from water samples of China mainland range from less than 0.5 to $977 \mathrm{ng} \mathrm{Sn/L}$ (Jiang et al., 2001). Another more important aspect is the widespread presence of significant concentrations of TBT and other butyltin compounds in aquatic environments within China, as shown in Table 1. Jiang et al. (2001) performed an extensive study of the presence of butyltin compounds in several of China's aquatic environments. They found high butyltin contamination in several of the major ports of China, including Qingdao, Dalian, Shanghai and Tianjin. At these ports, TBT, most likely from the use of antifouling paints on ships, made up the highest proportion of butyltin, ranging from below the detection limit ( $0.5 \mathrm{ng} \mathrm{Sn} / \mathrm{L})$ to $977 \mathrm{ng} \mathrm{Sn/L}$. The highest concentration of TBT, observed at the Qingdao North Sea Shipyard, is nearly one-half of the twelve-day $\mathrm{LC}_{100}$ value $(1.83 \mu \mathrm{g} \mathrm{Sn} / \mathrm{L})$ for adult rainbow trout (Seinen et al., 1981). Indeed, in four of the twenty-one locations studied, levels of TBT were high enough to cause chronic toxicity to local organisms. The high

Table 1

Distribution of butyltins in waters in various locations in China

\begin{tabular}{|c|c|c|c|c|c|}
\hline Location & $\mathrm{MBT}^{\mathrm{a}}{ }^{\mathrm{a}} \mathrm{ng} \mathrm{Sn} / \mathrm{L}$ & DBT, ${ }^{\mathrm{b}}$ ng Sn/L & $\mathrm{TBT}^{\mathrm{c}}{ }^{\mathrm{n}} \mathrm{g} \mathrm{Sn} / \mathrm{L}$ & Year of sampling & Reference \\
\hline Hong Kong & - & - & $<90$ to $1000^{d}$ & 1989 & Lau, 1991 \\
\hline Xiamen port & $372.3^{\mathrm{d}}$ & n.d. ${ }^{d, f}$ & $0.7^{\mathrm{d}}$ & 2002 & Huang et al., 2005 \\
\hline Shantou port & $338.1^{\mathrm{d}}$ & $0.02^{\mathrm{d}}$ & $0.74^{\mathrm{d}}$ & 2001-2002 & Huang et al., 2005 \\
\hline Huiyang port & $3286.8^{\mathrm{d}}$ & n.d. ${ }^{\mathrm{d}, \mathrm{f}}$ & $3.4^{\mathrm{d}}$ & 2002 & Huang et al., 2005 \\
\hline Opening of Bohai Bay & - & - & (range 0-14.7) & 2002 & Gao et al., 2004 \\
\hline Open sea area, South of Taiwan & 38.2 & 2.2 & n.d. ${ }^{f}$ & $2002^{\mathrm{e}}$ & Liu et al., 2002 \\
\hline Eastern and southern coastlines of China & 102.3 & 28.1 & 93.8 & $2002^{\mathrm{e}}$ & Zhou et al., 2002 \\
\hline Pearl River Delta & - & - & $21-39^{d}$ & 1996 & Chau, 2005 \\
\hline Tai Hu lake & (range n.d. ${ }^{\mathrm{f}}-13.2$ ) & n.d. ${ }^{\mathrm{f}}$ & n.d. ${ }^{\mathrm{f}}$ & 2003 & Yang et al., 2006c \\
\hline Three Gorges Reservoir & 12.1 (n.d. ${ }^{\mathrm{f}}-79.1$ ) & 40.7 (range n.d. ${ }^{\mathrm{f}}-416.8$ ) & 8.5 (range n.d. ${ }^{\mathrm{f}}-68.9$ ) & 2003 & Gao et al., 2006 \\
\hline Bohai Bay and Haihe River Basin & - & (range 7.07-64.84) & (range n.d. ${ }^{\mathrm{f}}-14.23$ ) & 2002 & Gao et al., 2004 \\
\hline Guanting reservoir & 138 (range 37-243) & 2.7 (range $2-3$ ) & n.d. ${ }^{\mathrm{f}}$ & 2000 & Liu et al., 2003 \\
\hline Yongding river & (range 30-1683) & (range $3-4$ ) & n.d. ${ }^{\mathrm{f}}$ & 2000 & Liu et al., 2003 \\
\hline Dalian New Shipyard 1 & 40.5 & 19.7 & 18.8 & 1998 & Jiang et al., 2001 \\
\hline Dalian New Shipyard 2 & 883.8 & 185.5 & 203.7 & 1998 & Jiang et al., 2001 \\
\hline Qinhuangdao Coal Port & 77.9 & 15.4 & n.d. ${ }^{\mathrm{f}}$ & 1999 & Jiang et al., 2001 \\
\hline Qinghuangdao small dock & 45.9 & 33.9 & 5.6 & 1999 & Jiang et al., 2001 \\
\hline Qinghuangdao transport station & n.d. ${ }^{f}$ & 32.8 & n.d. ${ }^{\mathrm{f}}$ & 1999 & Jiang et al., 2001 \\
\hline Shanhaiguan Shipyard & 50.1 & 50.1 & 22.2 & 1999 & Jiang et al., 2001 \\
\hline Tianjin Huanhai Shipyard & 34.1 & 10.2 & 17.2 & 1998 & Jiang et al., 2001 \\
\hline Tianjin First Navigation station & n.d. ${ }^{\mathrm{f}}$ & 60.3 & 31.8 & 1998 & Jiang et al., 2001 \\
\hline Tianjin Shipyard & 243.3 & 48.6 & 322.4 & 1998 & Jiang et al., 2001 \\
\hline Qingdao North Sea Shipyard & n.d. ${ }^{\mathrm{f}}$ & 24.0 & 976.9 & 1998 & Jiang et al., 2001 \\
\hline Qingdao Landing Stage & n.d. ${ }^{\mathrm{f}}$ & 5.0 & 4.4 & 1998 & Jiang et al., 2001 \\
\hline Yantai Yellow Sea Yulecheng & 70.4 & n.d. ${ }^{\mathrm{f}}$ & 28.0 & 1999 & Jiang et al., 2001 \\
\hline Yantai West of Jiahekou & 54.4 & 1.18 & n.d. ${ }^{\mathrm{f}}$ & 1999 & Jiang et al., 2001 \\
\hline Yantai Shuichan Grogshop & n.d. ${ }^{\mathrm{f}}$ & 3.3 & 1.2 & 1999 & Jiang et al., 2001 \\
\hline Yantai Huangzhuang & n.d. ${ }^{\mathrm{f}}$ & 2.44 & n.d. ${ }^{\mathrm{f}}$ & 1999 & Jiang et al., 2001 \\
\hline Breeding grounds of Yantai cold storage factory & n.d. ${ }^{\mathrm{f}}$ & 5.42 & 3.72 & 1999 & Jiang et al., 2001 \\
\hline Guangxi North Sea & 125.2 & n.d. ${ }^{\mathrm{f}}$ & 14.8 & 1998 & Jiang et al., 2001 \\
\hline East Sea, Lianyungang Port & 106.0 & n.d. ${ }^{\mathrm{f}}$ & n.d. ${ }^{\mathrm{f}}$ & 1999 & Jiang et al., 2001 \\
\hline Yangzi River, Jiangyin Jiucaidu Port & 132.3 & n.d. ${ }^{\mathrm{f}}$ & 10.0 & 1999 & Jiang et al., 2001 \\
\hline Yangzi River, Three Gorge Port & 85.7 & 1.5 & 0.8 & 1999 & Jiang et al., 2001 \\
\hline Taihu, Wuxi Yuantouzhu Park & n.d. ${ }^{\mathrm{f}}$ & n.d. ${ }^{\mathrm{f}}$ & n.d. ${ }^{\mathrm{f}}$ & 1999 & Jiang et al., 2001 \\
\hline Hangzhou West Lake Tourist Ship Port & 39.3 & 7.2 & 3.7 & 1999 & Jiang et al., 2001 \\
\hline Hangzhou West Lake & 82.8 & n.d. ${ }^{\mathrm{f}}$ & n.d. ${ }^{\mathrm{f}}$ & 1999 & Jiang et al., 2001 \\
\hline Qiantang River, Hangzhou Nanxingqiao Passenger Port & 55.2 & 2.1 & n.d. ${ }^{\mathrm{f}}$ & 1999 & Jiang et al., 2001 \\
\hline Qiantang River, Hangzhou Sanbao Port & n.d..$^{f}$ & 2.3 & 0.6 & 1999 & Jiang et al., 2001 \\
\hline Huangpu River, Shanghai Tourist Ship Port & n.d. ${ }^{\mathrm{f}}$ & 8.1 & 10.6 & 1999 & Jiang et al., 2001 \\
\hline Huangpu River, Shanghai Fuxing East Road Ship Port & 49.5 & 8.5 & 425.3 & 1999 & Jiang et al., 2001 \\
\hline Baiyangdian Lake & 202.9 & n.d. ${ }^{\mathrm{f}}$ & 6.2 & 1999 & Jiang et al., 2001 \\
\hline Yellow River, Huayuankou & n.d. ${ }^{\mathrm{f}}$ & 3.1 & n.d. ${ }^{\mathrm{f}}$ & 1999 & Jiang et al., 2001 \\
\hline Yunnan Dianchi Lake & 312.5 & 95.2 & 37.6 & 1999 & Jiang et al., 2001 \\
\hline Beijing Changchunyuan Lake & 64.8 & n.d. ${ }^{f}$ & n.d. ${ }^{\mathrm{f}}$ & 1999 & Jiang et al., 2001 \\
\hline Beijing Fuhai Lake & n.d. ${ }^{f}$ & 4.96 & n.d. ${ }^{\mathrm{f}}$ & 1999 & Jiang et al., 2001 \\
\hline
\end{tabular}

"-." Indicates that the data is not available.

a Monobutylin.

b Dibutylin.

c Tributylin.

d Indicates that units are given in $\mathrm{ng} / \mathrm{L}$.

e Indicates that sampling time was not specified. Date given is publication year.

f n.d. indicates that the concentration was below the detection limit of the methods used. 
proportion of TBT and the low proportion of its degradation products, MBT and DBT, observed in such locations as the Qingdao North Sea Shipyard and Shanghai Fuxing East Road ship port, indicate that TBT contamination (likely leached from ship hulls) was recent at the time of study. Locations such as the Dalian New Shipyard 2 and Yunnan Dianchi Lake had higher proportions of MBT and DBT, and this observation likely reflects the degradation of TBT with time or other sources of MBT and DBT (Jiang et al., 2001).

High TBT levels (90-1000 ng/L) were observed in samples from ambient coastal waters of typhoon shelters, marinas, mariculture grounds in Hong Kong, which were most likely the result of TBT leaching from fish nettings and vessels (Lau, 1991). Huang et al. (2005) added further evidence to the widespread and severe contamination of BTs along the Chinese coastlines. They performed a survey of organotin contamination of water samples from three large ports on the southeastern coastline of China, Xiamen, Shantou and Huiyang ports (Table 1). The MBT concentrations of the three ports were relatively high, ranging from 338 to $3287 \mathrm{ng} / \mathrm{L}$, with the highest concentration at the Huiyang port. Conversely, the TBT concentrations at these ports were relatively low, ranging from below detection limits to $9.8 \mathrm{ng} / \mathrm{L}$ at the Huiyang port. Differences in shipping activity at these ports, hydraulic events, seasonal variations and the distances from larger ports likely affected TBT concentrations at these locations. Interestingly, the concentration of TBT in the sediments of these three ports is high and suggests that MBT contamination may also be the result of desorption or resuspension of TBT-degradation products from sediment (see Section 2.2). In addition to studying the concentrations of BTs at these ports, this study also correlated adverse effects on the local ecosystem (i.e., the induction of imposex in gastropods) to organotin contamination (Huang et al., 2005).

As distances from the coastlines increased, the butyltin concentrations in water samples were observed to decrease. This observation is not surprising as one would expect decreased input sources of butyltin contamination and increased hydraulic exchange and dilution with increasing distance from the coastlines. Gao et al. (2004) studied butyltin in the open waters of Bohai Bay, where the concentrations of TBT (from below the detection limit to $14.2 \mathrm{ng} \mathrm{Sn} / \mathrm{L}$ ) were much lower than the concentrations of TBT in water samples from seaports around Bohai Bay (from below the detection limit to $322.4 \mathrm{ng} \mathrm{Sn/L)} \mathrm{(Jiang} \mathrm{et} \mathrm{al.,} \mathrm{2001).} \mathrm{Liu} \mathrm{et} \mathrm{al.} \mathrm{(2002)}$ observed a similar trend of butyltin concentrations in Taiwan coastal waters. In an open sea area south of Taiwan, average concentrations of BTs in water samples (MBT: $38.2 \mathrm{ng} \mathrm{Sn} / \mathrm{L}, \mathrm{DBT}$ : $2.2 \mathrm{ng} \mathrm{Sn} / \mathrm{L}$, and TBT: below detection limits) (Liu et al., 2002) were much lower than those from samples collected along the eastern and southern coastlines (MBT: $102.3 \mathrm{ng}$ Sn/L, DBT: $28.1 \mathrm{ng}$ Sn/L, and TBT: $93.8 \mathrm{ng} / \mathrm{L}$ ) (Zhou et al., 2002).

Other areas where TBT concentrations were found to be relatively low are the Pearl River Delta in Southern China and Tai Hu Lake in Central China. The Pearl River Delta, including Hong Kong and Macao, has recently experienced rapid growth in its industrial and agricultural activities along with increased activities in its main harbors. Surface water samples from this area indicated that TBT concentrations ranged from 21 to $39 \mathrm{ng} / \mathrm{L}$ (Yuan et al., 2001). The area of the Tai Hu Lake also had relatively low concentrations of BTs. The concentrations of MBT, DBT, and TBT in most water samples were below detection limits, with the exception of one water sample with a low concentration of MBT at $13.2 \mathrm{ng} / \mathrm{L}$ (Yang et al., 2006c). Although the concentration of TBT is relatively low compared to concentrations of TBT in seaports around Bohai Bay (TBT: from undetected to $322 \mathrm{ng} \mathrm{Sn/L;} \mathrm{Jiang} \mathrm{et} \mathrm{al.,} \mathrm{2001),} \mathrm{TBT} \mathrm{at} \mathrm{this}$ level is still possible causing imposex of gastropods.

The Three Gorges Reservoir, at the Yangtze River Basin, also had significant concentrations of BTs in its waters. The average concentrations of MBT, DBT and TBT in water samples of the Three
Gorges Reservoir were 12.1, 40.7 and $8.5 \mathrm{ng}$ Sn/L, respectively (Gao et al., 2006). Additionally, water sampled from two monitoring stations, Wanglongmen and Xiangxihe, contained higher concentrations of butyltin than the recommended criterion $(63 \mathrm{ng} / \mathrm{L})$ set for protecting aquatic biota (EPA-822-B-02-001, 2002). Interestingly, at these monitoring stations, MBT and DBT, but not TBT, were detected, which suggested that there existed an input source for MBT and DBT, such as leaching of PVC stabilizers. At other sites of the reservoir (i.e. Daxigou and Shaiwangba), there are some boating activities, and it is likely that antifouling paints on these boats were part of the source of TBT at these locations. Like the Three Gorges Reservoir, the Guanting Reservoir in northern China has also been contaminated with methyltin and butyltin compounds. This reservoir is of particular importance as a water supply source to Beijing, in northern China. Monomethyltin (MMT), dimethyltin (DMT) and trimethyltin (TMT) pollutions have reached surprisingly high average levels of 259, 239 and $259 \mathrm{ng} / \mathrm{L}$, respectively (Liu et al., 2003). These concentrations were most likely the result of anthropogenic inputs as well as methylation in the aquatic environment. With regards to butyltin compounds, relatively high average levels of MBT (138 ng/L) and low levels of DBT (2.7 ng/L) were detected and are, as in the case of the Three Gorges Reservoir, most likely a result of PVC leaching (Liu et al., 2003). No TBT was detected at the Guanting Reservoir, which is attributed to the low number of anthropogenic inputs of TBT, i.e. boats/vessels. Downstream of the Guanting reservoir, the Yongding River had similarly high levels of methyltin and butyltin, which directly affected the groundwater supply used by the residents of Beijing (Liu et al., 2003). Although the contamination levels by organotins were not high enough to cause acute poisoning to humans, the potential risk assessment should be carried out in view of the environmental safety.

In general, published reports show that organotin, especially butyltin, contamination in China is both significant and widespread. Waters at seaports with high shipping activities suffer from the highest concentrations of BTs, particularly TBT. Besides seaports, reservoirs also have been reported to have high concentrations of BTs as a result of PVC leaching. Some areas that (at the time of study) do not seem to have serious butyltin contamination of surface waters are the Tai Hu Lake, Pearl River Delta and open sea areas with greater distances from shipping hubs. The distribution of BTs in waterways around China makes it necessary to continue efforts to monitor the contamination levels and enact the control measures in the future.

\subsection{Distribution of organotins in sediments}

The long degradation period of organotins in sediments creates a long-term pollution source to the water column, resulting from the release of accumulated organotins through resuspension and/ or desorption (Unger et al., 1988; Dowson et al., 1993). The presence of butyltin species in sediment thus directly affects its surrounding aquatic ecosystem. Several studies have reported butyltin presence in sediments of areas with high shipping traffic in China (Table 2).

In the Shenzhen and Hong Kong region of China, Zhou et al. (2002) reported that average levels of MBT, DBT and TBT in sediments were 104, 36 and $354 \mathrm{ng} / \mathrm{g}$, respectively. In another study of Hong Kong sediments, Lau (1991) reported concentrations of TBT as high as $1160 \mathrm{ng} / \mathrm{g}$ in sediments. These butyltin concentrations are high compared to other locations in China and suggest that the intensive shipping activities at Hong Kong ports contribute significantly to butyltin sediment contamination. TBT concentrations in the sediments at the ports of Xiamen, Shantou and Huiyang, ranging from 0.3 to $174.7 \mathrm{ng} / \mathrm{g}$ (2.36-82.86\% of total butyltin sediment concentrations), were lower than those in sediments in Hong Kong (Huang et al., 2005). Furthermore, butyltin compound distribution in the sediments of the three ports varied significantly. Xiamen port 
Table 2

Distribution of butyltins in sediments in various locations in China

\begin{tabular}{|c|c|c|c|c|c|}
\hline & MBT, ng/g & DBT, ng/g & TBT ng/g & Sampling year & Reference \\
\hline Shenzhen and Hong Kong & 104 & 36 & 354 & Published 2002 & Zhou et al., 2002 \\
\hline Hong Kong & - & - & $<14$ to 1160 & 1988 & Lau, 1991 \\
\hline Xiamen Port & $16.8 \mathrm{dw}$ & n.d. & $77 \mathrm{dw}$ & 2002 & Huang et al., 2005 \\
\hline Shantou Port & $16.17 \mathrm{dw}$ & $0.2 \mathrm{dw}$ & $3.45 \mathrm{dw}$ & $2001-2002$ & Huang et al., 2005 \\
\hline Huiyang Port & $75.3 \mathrm{dw}$ & $0.1 \mathrm{dw}$ & $6.3 \mathrm{dw}$ & 2002 & Huang et al., 2005 \\
\hline Tai Hu lake & $0.33-0.95 \mathrm{ng} \mathrm{Sn} / \mathrm{g} \mathrm{dw}$ & $0.05-0.15 \mathrm{ng} \mathrm{Sn} / \mathrm{g} \mathrm{dw}$ & n.d. & 2003 & Yang et al., 2006c \\
\hline Jiulongjang estuary & $0.07^{\mathrm{a}}-1.76 \mathrm{ng} \mathrm{Sn} / \mathrm{g} \mathrm{dw}$ & n.d.-6.99 ng Sn/g dw & n.d. $-24.03 \mathrm{ng} \mathrm{Sn} / \mathrm{g} \mathrm{dw}$ & 1996-1999 & Yuan et al., 2001 \\
\hline Minjiang estuary & n.d. $-0.12^{a}$ & n.d. $-0.03^{a}$ & n.d. $-0.02^{\mathrm{a}}$ & 1996 & Yuan et al., 2001 \\
\hline Zhujiang estuary & $0.09^{\mathrm{a}}$ & $0.04^{\mathrm{a}}$ & n.d. & 1996 & Yuan et al., 2001 \\
\hline Victoria Harbor, Hong Kong & n.d.-12.62 & n.d. -1.53 & n.d. -0.91 & 1994 & Yuan et al., 2001 \\
\hline Pearl River Delta & - & - & $1.7-379.7 d w$ & Published 2003 & Zhang et al., 2003 \\
\hline Fuhai in Yuanmingyuan park & 19.7 & - & 0.46 & Published 2001 & Liu and Jiang, 2001 \\
\hline
\end{tabular}

"-." Indicates that the data is not available.

a Indicates below detection limit.

had the highest TBT sediment concentration, and Huiyang port had the highest MBT sediment concentration (Table 2). Differences in butyltin concentrations are most likely a result of variations in the movement of dirt and sand in nearby waterways which allow for the sedimentation of butyltin species (Huang et al., 2005).

Yuan et al. (2001) analyzed sediment samples from the Jiulongjiang, Minjiang and Zhujiang estuaries on the east coast of China and compared these to sediments from the Victoria Harbor in Hong Kong, China. In all locations, butyltin contamination of sediments was not serious (Table 2). Butyltin levels, especially TBT, in the sediments of the West Harbor of the Jiulongjiang estuary were higher than those in sediments at other locations in this study and are likely the result of restricted seawater exchange conditions in the West Harbor (Yuan et al., 2001). It is interesting to note the differences of butyltin concentrations in sediments among different studies in Hong Kong (Table 2). The wide variations of concentrations highlight the differences in sampling locations and times and emphasize the importance of a detailed and consistent monitoring plan.

In the Pearl River Delta, Zhang et al. (2003) reported TBT concentrations in sediments ranged from 1.7 to $379.7 \mathrm{ng} / \mathrm{g}$, which varies from the previous estimate of TBT concentrations of $0.91 \mathrm{ng} /$ $\mathrm{g}$ (Yuan et al., 2001). Different sample locations may have resulted in inconsistencies between the two studies. Both estimates of TBT concentrations in sediments are relatively low compared to other parts of the world (Fu et al., 2003). Likewise, butyltin concentrations in the Tai Hu Lake were relatively low compared to other locations in China. MBT and DBT were reported at 0.33-0.95 and $0.05-0.15 \mathrm{ng} / \mathrm{g}$, respectively. No TBT was detected in any sediment samples of the Tai Hu Lake (Yang et al., 2006c).

An interesting study of sediments of a recreational site at Fuhai of Yuanmingyuan Park, Beijing, found the mean concentration of MBT and TBT to be 19.7 and $0.46 \mathrm{ng} / \mathrm{g}$, respectively (Liu and Jiang, 2001). Small amounts of TBT most likely leached from the entertainment boats popularly used in this park. In the winter, as park attendance was low and the boats were used less, the majority of the TBT degraded into MBT.

In general, the distribution of butyltin in sediments in China is high in locations with high shipping activity, such as Hong Kong, Shenzhen and the West Harbor in the Jiulongjiang estuary and is low at non-industrial sites and in locations where water exchange conditions are efficient. Currently, there is limited number of studies considering the effects of TBT-degradation and its products on aquatic systems. In order to better understand the fate of TBT in these systems, butyltin contamination monitoring in sediments will become increasingly important.

\subsection{Distribution of organotins in foods}

Organotin compounds can be found in some foods, such as seafoods, meat, farm products and liquid foods. No obvious degradation of BTs occurs in the cooking process (Li et al., 2003; Zhou et al., 2002, 2001). Research on the contamination levels of organotins in food may be helpful to evaluate the food safety.

\subsubsection{Distribution of organotins in marine products}

Several studies have provided information about the distribution of organotins in Chinese marine products such as fish and shellfish (Zhou et al., 2002, 2001; Yang et al., 2006b, 2006d; Li et al., 2003). In addition to providing information about organotin distribution in China, these reports have also been helpful in determining hotspots of contaminated food sources that may present serious human health risks. Table 3 summarizes the average concentrations of MBT, DBT and TBT found in samplings of marine products, mostly molluscs, from different coastal cities in China. It should be noted that these are averaged values used for a general distribution and do not take into consideration the unique characteristics of individual marine products. For more details on the specific distribution among different marine products at different locations, references have been provided.

The southeastern to northeastern China coastlines, specifically an area called the Bohai coast, have been extensively studied for organotin contamination (Zhou et al., 2002, 2001; Yang et al., 2006b, 2006d; Li et al., 2003). Several cities in this region have very active shipping industries that have resulted in serious problems with aquatic pollution. Butyltin concentrations in marine products (i.e. fish and shellfish) from several of these coastal cities have been reported in recent years (Table 3). In 2001, a survey of the butyltin concentrations in 52 marine products sampled from 7 cities along the Bohai coast was performed by Zhou et al. (2001). The concentration of butyltin compounds ranged from the limit of quantification (<19.8 ng Sn/g) to $18007 \mathrm{ng} \mathrm{Sn/g} \mathrm{w.w.} \mathrm{(average} 408 \mathrm{ng} \mathrm{Sn/}$ $\mathrm{g}$ w.w.). The concentrations of TBT, DBT and MBT ranged from 6.9 to $17175,5.2$ to 692 , and 7.8 to $140 \mathrm{ng} \mathrm{Sn/g} \mathrm{w.w.,} \mathrm{respectively} \mathrm{(Zhou}$ et al., 2001). In 2003, 113 marine product samples were collected from 13 cities along the Bohai Coast. In these samples, butyltin concentrations ranged from 2.5 to $397.6 \mathrm{ng} \mathrm{Sn} / \mathrm{g} \mathrm{w.w}$. (average $63 \mathrm{ng} \mathrm{Sn} / \mathrm{g}$ ), and TBT, DBT and MBT ranged from 2.8 to 383.9, 3.2 to 158.1, and 2.5 to $52.2 \mathrm{ng} \mathrm{Sn/g} \mathrm{w.w.,} \mathrm{respectively} \mathrm{(Yang} \mathrm{et} \mathrm{al.,} \mathrm{2006b).}$

These studies provide several important observations. Firstly, TBT contamination made up the major proportion of butyltin in both samplings and in all locations (Table 3 ). This finding and the locations of the cities among shipping hubs suggested that TBT input sources, such as antifouling paints on ship hulls, may have contributed significantly to marine product contamination. A second observation between the two studies was the substantial butyltin contamination in Dalian (30-100 times higher than other cities) (Yang et al., 2006b; Zhou et al., 2001). As a result of being a large and important seaport in China, Dalian often has a high shipping traffic which has presumably led to serious butyltin contamination of its marine products. A large decrease in the 
Table 3

Average values of butylins found in aquatic gastropods in different Chinese cities

\begin{tabular}{|c|c|c|c|c|c|c|c|}
\hline Location & MBT ng Sn/g wet weight & DBT ng Sn/g wet weight & TBT ng Sn/g wet weight & $\begin{array}{l}\text { Total butyltins, ng Sn/g } \\
\text { wet weight }\end{array}$ & $(\mathrm{TBT} / \Sigma \mathrm{BTs}) \%$ & Sampling year & Reference \\
\hline Dalian & 7.95 & 12.04 & 102.64 & 122.63 & 83.70 & 2003 & Yang et al., 2006c \\
\hline Yingkou & 4.53 & 8.71 & 24.58 & 37.80 & 65.01 & 2003 & Yang et al., 2006c \\
\hline Jinzhou & 4.83 & 15.33 & 30.81 & 50.98 & 60.44 & 2003 & Yang et al., 2006c \\
\hline Huludao & 7.39 & 17.01 & 48.18 & 72.59 & 66.37 & 2003 & Yang et al., 2006c \\
\hline Shanhaiguan & 19.93 & 36.63 & 45.28 & 101.85 & 44.46 & 2003 & Yang et al., 2006c \\
\hline Beidaihe & 5.24 & 9.99 & 72.70 & 87.93 & 82.68 & 2003 & Yang et al., 2006c \\
\hline Tianjin & 9.05 & 11.55 & 64.05 & 84.66 & 75.65 & 2003 & Yang et al., 2006c \\
\hline Shouguang & 3.33 & 3.87 & 10.03 & 17.25 & 58.16 & 2003 & Yang et al., 2006c \\
\hline Longkou & 7.65 & 12.55 & 53.75 & 73.93 & 72.71 & 2003 & Yang et al., 2006c \\
\hline Laizhou & 8.40 & 11.56 & 32.03 & 51.98 & 61.63 & 2003 & Yang et al., 2006c \\
\hline Penglai & 2.60 & 12.73 & 34.02 & 49.36 & 68.93 & 2003 & Yang et al., 2006c \\
\hline Yantai & 4.75 & 14.69 & 26.09 & 48.64 & 53.64 & 2003 & Yang et al., 2006c \\
\hline Weihai & 4.68 & 7.53 & 38.68 & 50.88 & 76.02 & 2003 & Yang et al., 2006c \\
\hline Beijing & 2.67 & 5.75 & 37.24 & 45.65 & 81.57 & $2001^{a}$ & Zhou et al., 2001 \\
\hline Dalian & 32.12 & 143.94 & 3538.75 & 3714.77 & 95.26 & $2001^{\mathrm{a}}$ & Zhou et al., 2001 \\
\hline Qinhuangdao & 23.40 & 21.10 & 74.50 & 119.00 & 62.61 & $2001^{a}$ & Zhou et al., 2001 \\
\hline Tianjin & n.d. & 3.86 & 38.71 & 42.57 & 90.94 & $2001^{a}$ & Zhou et al., 2001 \\
\hline Qingdao & 1.74 & 2.68 & 52.02 & 56.44 & 92.17 & $2001^{\mathrm{a}}$ & Zhou et al., 2001 \\
\hline Yantai & 0.86 & 0.44 & 36.72 & 38.02 & 96.58 & $2001^{a}$ & Zhou et al., 2001 \\
\hline Lianyunguan & 4.58 & 11.40 & 97.76 & 113.74 & 85.95 & $2001^{a}$ & Zhou et al., 2001 \\
\hline Xiamen port & 85.25 & 0.27 & 17.30 & 102.82 & 16.83 & 2002 & Huang et al., 2005 \\
\hline Shantou port & 43.85 & n.d. & 3.55 & 47.40 & 7.49 & 2001 & Huang et al., 2005 \\
\hline Huiyang port & 38.75 & n.d. & 5.80 & 44.55 & 13.02 & 2002 & Huang et al., 2005 \\
\hline Tai Hu Lake & 8.74 d.w. & 10.5 d.w. & $43.6^{\mathrm{d}}$ & $62.8^{\mathrm{d}}$ & 69.40 & 2004 & Huang et al., 2005 \\
\hline Pearl River Delta & - & - & $<18.8^{\mathrm{c}}$ & - & - & $2003^{a}$ & Huang et al., 2005 \\
\hline Hong Kong & - & - & - & $500^{c}$ & - & Published 2002 & Sudaryanto et al., 2002 \\
\hline Hong Kong & - & - & $672^{\mathrm{b}}$ & - & - & $1991^{\mathrm{a}}$ & Lau, 1991 \\
\hline Taiwan & - & - & - & $236-2501^{\mathrm{c}}$ & - & 1997-1998 & Dong et al., 2004 \\
\hline Taiwan-winter & - & - & - & $91-1658^{\mathrm{b}}$ & - & $1998^{\mathrm{a}}$ & Hung et al., 1998 \\
\hline Taiwan-summer & - & - & - & $99-763^{b}$ & - & $1998^{a}$ & Hung et al., 1998 \\
\hline
\end{tabular}

"_." Indicates that the data is not available.

a Indicates that the publication year, sampling year unknown.

b Indicates units of $\mathrm{ng} / \mathrm{g}$ dry weight.

c Indicates units of $\mathrm{ng} / \mathrm{g}$ wet weight.

d Indicates units of ng Sn/g dry weight.

average butyltin concentrations in marine products from $3715 \mathrm{ng} \mathrm{Sn/g}$ wet weight in 2000 (Zhou et al., 2001) to $123 \mathrm{ng} \mathrm{Sn/g}$ wet weight in 2003 (Yang et al., 2006b) (Table 3) is interesting. It is possibly the result of the collection of the mollusc Laternula limicola from largely polluted areas or its ability to accumulate high levels of BTs. Other cities, besides Dalian, that had relatively high levels of butyltin concentrations in marine products included Qinhuangdao, Lianyungang, Tianjin, Yantai and Beidaihe (Yang et al., 2006b; Zhou et al., 2001). In 2003, nearly $20 \%$ of the sampled marine products contained butyltin concentrations that exceeded normal tolerable average residue levels for human consumption (Yang et al., 2006b). Most of the butyltin contamination (45-100\%) in these marine products was from TBT, and it has been estimated that TBT concentrations in marine products are three orders of magnitude higher than those in the corresponding seawaters (Zhou et al., 2002, 2001). Also, compared to TBT concentrations in mussels in the USA, Australia, Canada and Japan, the TBT levels in aquatic molluscs of the Bohai coast were relatively high (Yang et al., 2006b).

Several studies have provided information about the presence of butyltin compounds in marine products around busy shipping locations around China. Huang et al. (2005) studied the concentrations of BTs in molluscs in large ports along the southeastern coastlines of China. They reported that the mean total butyltins concentration in Thais clavigera collected from Xiamen, Shantou and Huiyang ports was $69 \mathrm{ng} / \mathrm{g}$ w.w. (Huang et al., 2005). Of the three ports, Xiamen had the highest level of butyltins, with mean concentrations of MBT, DBT and TBT reported to be 85.2, 0.27, and $17.3 \mathrm{ng} / \mathrm{g}$ w.w., respectively (Huang et al., 2005). MBT concentrations of marine products at these ports were considerably higher in comparison with marine products of other locations. This observation was consistent with MBT levels in the water samples at these ports and was likely due to shipping activity throughput and/or TBT-degradation from the sediment (see Section 2.2). In Taiwan, butyltin concentrations ranged from 236 to $2501 \mathrm{ng} / \mathrm{g} \mathrm{w} . \mathrm{w}$. in ponyfish (Dong et al., 2004) and from 91 to $1658 \mathrm{ng} / \mathrm{g} \mathrm{d.w}$. in oysters (Hung et al., 1998). Seasonal variances were found to affect butyltin accumulation among organisms, with winter having the highest butyltin concentrations (Dong et al., 2004; Hung et al., 1998). High concentration of butyltin in organisms in winter is possibly induced by seasonally mediated physiological changes, such as dilution due to growth and metabolic compensation (Dong et al., 2004). In Hong Kong, total butyltin concentrations in mussels were reported to be up to $500 \mathrm{ng} / \mathrm{g}$ w.w. (Sudaryanto et al., 2002), and TBT concentrations in clams were measured to be up to $672 \mathrm{ng} /$ g d.w. (Lau, 1991). The concentrations of butyltin contamination in Hong Kong marine products compared to other locations were relatively high (Table 3 ). However, concentrations of butyltins in mussels and fish of the Tai Hu Lake were found to be much lower, ranging from 24.94 to $181.23 \mathrm{ng} / \mathrm{g} \mathrm{d} . \mathrm{w}$. with mean concentrations of MBT, DBT and TBT measured at 8.74, 10.5 and $43.6 \mathrm{ng} / \mathrm{g}$ d.w., respectively (Yang et al., 2006c). A similar survey of TBT concentrations in fish, mussel, and shrimp from the Pearl River Delta found that TBT concentrations in organisms were less than $18.8 \mathrm{ng} / \mathrm{g} \mathrm{w} . \mathrm{w}$. (Zhang et al., 2003). The low concentrations of BTs in marine products in Tai Hu Lake and the Pearl River Delta are consistent with low concentrations of BTs in water samples at these locations.

In summary, the presence of organotin compounds, especially butyltin, in aquatic molluscs around China is indisputable. In 
general, butyltin concentrations in marine products matched well with butyltin concentrations of water samples at the corresponding locations. As in the case of water samples, TBT made up the largest proportion of butyltin contamination in marine products. Continuous monitoring of butyltin contamination in marine products is important as the high butyltin level in marine products will result in a serious human health risk.

\subsubsection{Distribution of organotins in other foods}

In addition to butyltin presence in commercial marine products, BTs have also been found in several other food types in China. In a survey of 12 types of foods in 4 districts of China, Zhou et al. (2004) found that the average butyltin level was $15.5 \mathrm{ng} \mathrm{Sn/g}$ with higher average butyltin levels in Southern China districts (25.3 ng Sn/g) than Northern China districts (5.6 ng Sn/g) (Zhou et al., 2004). It is likely that larger activities of agriculture and industry in southern China contributed to the butyltin concentrations in its food. Of the different food types surveyed, freshwater fish had the highest mean butyltin level (66.7 ng Sn/g). Compared to the European Union Scientific Cooperation Report (2003) describing mean levels of MBT, DBT and TBT in fish (10.1, 16.8 and $28.4 \mathrm{ng} \mathrm{Sn} / \mathrm{g}$, respectively), the reported butyltin levels in Chinese fish were relatively higher. Other samples of food, including beans, fruits, eggs and meat, contained butyltin concentrations ranging from 13.5 to $29.4 \mathrm{Sn} n g / \mathrm{g}$. Low butyltin levels, ranging from 2.5 to $12.8 \mathrm{ng} \mathrm{Sn} / \mathrm{g}$, were found in vegetables, potatoes, sugar, milk, wine and beverage (Zhou et al., 2004). The main source of butyltin contamination in fish is exposure to butyltins leaching of antifouling paints in water. Butyltin can also be introduced into food products through its consumption by livestock, especially poultry, through the feeding of contaminated fish and snails. Contaminated sludge and pesticides may be another source of contamination for agriculture products. Furthermore, the use of butyltin-stabilized PVC products in food packaging can also cause butyltin contamination.

The effects of food packaging, such as the plastic used to package liquid food and agglomerated cork stoppers in alcoholic beverage, have been studied in further detail. Liu and Jiang (2002) surveyed alcoholic beverages available for retail purchase in China for the presence of butyltin compounds. Among 44 samples that included wine, liquor and champagne, levels of MBT and DBT ranged from less than 0.016 to 5.687 and from less than 0.0022 to $33.257 \mu \mathrm{g} \mathrm{Sn} /$ $\mathrm{L}$, respectively. TBT levels were relatively low in these samples, with the highest level measured at $0.269 \mu \mathrm{g} \mathrm{Sn} / \mathrm{L}$. With the exception of a wine sample imported from Spain, wines bottled in Shanghai, China contained the highest butyltin concentration (MBT: $5.687 \mu \mathrm{g} \mathrm{Sn} / \mathrm{L}$, DBT: $33.257 \mu \mathrm{g} \mathrm{Sn} / \mathrm{L}$, and TBT: $13.567 \mu \mathrm{g} \mathrm{Sn} / \mathrm{L})$. In general, dry wines were found to contain more DBT than sweet wines, and liquor contained less total butyltins than wine. Compared with concentrations of butyltin in other foods in China, the butyltin concentrations in Chinese alcoholic beverages were relatively low. Butyltin contamination in wine may come from sources such as agglomerated cork stoppers. Jiang et al. (2004) found that all overseas agglomerated cork stoppers investigated contained mono- and/or dibutyltin, which were not present in domestic agglomerated cork products.

Presently, there is a limited amount of information about organotin contamination of food in China. From the available studies, the concentration of BTs in food in China appears to follow the following trend: freshwater fish > other animal foods (meat, eggs) $>$ farm products (vegetables, potatoes, sugar) $>$ liquid food (milk, wines and beverages). Additionally, butyltin contamination in foods is higher in well-developed industrial areas. Although, in general, the concentration of organotins in food is relatively low, concerns over its presence are high because of the endocrine disruption effects and high toxicity associated with butyltin compounds (Fent, 1996). In some locations of China, organotin contamination in food is already high and organotin usage continues to increase (Layman, 1995). It is thus imperative that effective actions be taken as soon as possible to prevent future human health risks.

\section{Impacts of organotins on marine environment and human health}

\subsection{Accumulation of organotins in marine biota}

Organotins are one of the most toxic agents that have been released into the environment by anthropogenic activities (Gibbs et al., 1988). As such, it is of concern that many marine organisms have been shown to bio-accumulate organotin compounds to a large degree. In phytoplankton, the bioconcentration factor (BCF) of TBT has been reported to be between 5000 to 30000 (Zhang, 2001). The BCF of freshwater algae, Scenedesmus obliquus, for TBT and triphenyltin (TPT) has been estimated to be even greater with values larger than 332000 and 114000 , respectively (Huang et al., 1993). For plankton of the Otsuchi Bay, Japan, the BCFs of TBT and TPT were reported to range from 3000 to 132432 and 2222 to 74 444, respectively (Harino et al., 1998). In molluscs, BCF of TBT ranged from 1000 to 60000 (Gibbs and Bryan, 1986; Zhou et al., 1994). In particular, the bivalve species of molluscs can accumulate much more butyltin than many other marine species, including snails, shrimp, fish, and crab (Zhou et al., 2001). Among mollusc, Mya arenaria has a very strong ability to accumulate butyltin compared with the other bivalves sampled (Zhou et al., 2003; Yang et al., 2006a, 2006b).

With such high bioaccumulation factors, it is important to understand the effects of organotins on marine organisms. In past studies, it has been demonstrated that trialkyltins, such as TBT, can prevent the photosynthetic phosphorylation of chlorophylls in algae (Sun et al., 2005). In molluscs, it has also been demonstrated that TBT act as an endocrine disrupting chemical (Matthiessen and Gibbs, 1998). Low levels of TBT (ng/L) can cause such chronic toxic effects as shell calcification in oysters and the induction of imposex phenomenon in gastropods (Bryan and Gibbs, 1991; Gibbs and Bryan, 1996). Imposex phenomenon refers to the development of male sexual organs in female gastropods (Smith, 1971). Such masculinization causes reproductive failures in females and thus can cause the extinction of entire populations (Gibbs and Bryan, 1986). The presence of organotin compounds used as biocides in antifouling paints has been shown to induce imposex (Smith, 1981a, 1981b, 1981c; Bryan et al., 1987, 1988). In total, imposex has been documented in over 150 gastropod species (Matthiessen et al., 1999). In the coastal waters of China, imposex of gastropods is a widely reported problem related to organotin pollution (Shi et al., 2005). Indeed, among the countries of the world, Asia is one of the most organotin contaminated, where imposex has been shown in $100 \%$ of oysters in some ports of Taiwan and Japan (Sun et al., 2005).

Concerns over the bioaccumulation of organotins in marine organisms are further validated because of the trophic magnification of such compounds as TPT and TBT in the marine food web. Hu et al. (2006) reported that obvious magnification of TPT occurred in marine food webs with a trophic magnification factor (TMF) of 3.70, while TMF of TBT is only 0.59 . Other studies also revealed that no obvious magnification of TBT occurred in food web. Organotin compounds have also been found in seafowl, the highest trophic level of the marine food web. However, it should be noted that TBT levels in seafowl were much lower than those found in organisms at lower trophic levels and thus presumably no obvious magnification of TBT occurred in the marine food web (Tanabe et al., 1998; Kannan et al., 1998, 1996; Stäb et al., 1996). In addition to the marine food web, there have been reports describing high organotin 
concentrations in marine mammals all over the world (Hoeh, 2001). One study has even found measurable butyltin concentrations in human livers, most likely the result of the consumption of seafood (Kannan and Falandysz, 1997). Within mammals, organotin compounds have been shown to cause immunotoxicity, neurotoxicity, skin and eye irritation, mutagenicity, and carcinogenicity (Fent, 1996). Although no experiments have been performed, adverse chronic effects of organotins on humans have been documented through organotin poisoning incidences (see Section 3.2) (Jiang and Zhou, 2000; Jiang et al., 2000). Acute exposure to high levels of organotin compounds can cause humans to feel sick and display symptoms of dizziness and nausea (Zhou et al., 2001).

In general, the effects of organotin contamination of the marine environment are not likely to be limited to organisms living in the water but also to those who consume seafoods from the marine ecosystems.

\subsection{Ecotoxicological risk assessment of organotins on human health}

Seafood is an important source of protein for the diet of many people around the world, and thus the consumption of BTcontaminated seafood could cause adverse effects to human health. Currently, the toxicology of organotin compounds to humans is not fully understood (WHO, 1990), but organotin toxicity to animals can be extrapolated to humans. Penninks (1993) estimated the tolerable daily intake (TDI) of TBT to be $0.25 \mu \mathrm{g} / \mathrm{kg} /$ body weight/day based on the observed effects of TBT on the immune functions of rats. Belfroid et al. (2000) also calculated the tolerable average residue levels (TARLs) for TBT and DBT in seafood for human consumption with the following formula where TDI is the total daily intake and bw is the body weight:

$\mathrm{TARL}=\frac{(\mathrm{TDI} \times 60 \mathrm{~kg} \text { bw })}{\text { average daily seafood consumption }}$

According to the average seafood consumption of a Chinese person (average weight of $60 \mathrm{~kg}$ ), $68.8 \mathrm{~g} /$ day (FAO, 1997-1999), TARL for seafood in China is estimated to be $90.8 \mathrm{ng} \mathrm{Sn} / \mathrm{g}$ (Yang et al., 2006b). As stated in Section 2.3.1, in a sampling study of 113 marine products in 13 coastal cities of China, the average butyltin contamination level was lower than the TARL value. However, $20 \%$ of the total samples, those from highly polluted areas, exceeded the TARL value (Yang et al., 2006b). Average concentrations of TBT and DBT in marine products from the Xiamen, Shantou, Huiyang ports, Tai Hu Lake and the Pearl River Delta were lower than the recommended TARL value for China. However, the concentrations of TBT and DBT in marine products from aquaculture areas in Hong Kong and in oysters in Taiwan exceeded the recommended TARL value for China. It should be noted that at many of these sampling locations, it is possible that the local population consumes more than the estimated average of $68.8 \mathrm{~g} /$ day because of greater availability of seafood and thus may be at higher risk of organotin exposure (Yang et al., 2006b).

In recent years, there have been acute poisoning events caused by organotin exposure in food in China. In 1998, employees working for a company that produces plastic window blinds in Boluo County, Guangdong Province, China experienced organotin exposure when using TMT as a plastic stabilizer with no protective equipment (Sun et al., 2005). Eighteen employees were reported to be affected by TMT exposure, with one case resulting in death. In another incident during Chinese New Year in 1999, the consumption of methyltin-contaminated lard affected more than 1000 people (Jiang et al., 2000). Hundreds of people were hospitalized and three deaths occurred as a result of methyltin exposure. Autopsies showed that victims' hearts, kidneys, livers and stomachs contained extremely high levels of methyltin compounds with ranges of TMT and DMT concentrations from 0.10 to $1.93 \mu \mathrm{g} / \mathrm{g}$ w.w. and the range of total tin from 0.03 to $5.02 \mu \mathrm{g} / \mathrm{g} \mathrm{w} . \mathrm{w}$. (Jiang et al., 2000). As these incidences are largely preventable, immediate action should be taken to prevent future human harm from organotin exposure.

\section{Monitoring TBT in marine environments using biomarkers}

Chemical determination of organotin concentrations is both complicated and expensive, which has caused a need for the development of simpler and more convenient biological monitoring methods. Biological monitoring methods also have the advantage of being able to more accurately reflect the polluted extent of an ecosystem as native biota share similar exposures to pollution within the environment. Furthermore, biological activities can also, to some extent, document the history of accumulation of organotins. Several studies have shown that there is a correlation between the extent of imposex observed in gastropods and the contamination level of organotins (Cleary, 1985). Many countries have developed methods that use imposex status of native gastropods to predict contamination of aquatic environments. Imposex of gastropods in China has been widely observed in organotin-polluted coastal waters (Shi et al., 2005), however, few cases have been reported which used this phenomenon for biological monitoring. The following reviews the preliminary research about species that have been considered for biomarker candidates in China in the future.

\subsection{Biomarker for organotin accumulation in aquatic systems}

M. arenaria, belonging to Lamellibranchia, Eulamellibranchia and Myidae, can be found in the eastern open oceans of Russia, Bering Strait, western oceans of North America, northern ocean of Japan and Korea, the Yellow Sea, and Bohai Sea of China. This species of molluscs has been observed to have a strong ability to accumulate high concentration of TBT (Zhou et al., 2003; Yang et al., 2006a; Yang et al., 2006b). Furthermore, fast uptake and slow elimination of butyltins by $M$. arenaria can be modeled with first order kinetics. Its butyltin bioaccumulation characteristics coupled with the ability to predict accumulation with first order kinetics make this species an ideal biomarker candidate for estimating butyltin accumulation in aquatic systems (Yang et al., 2006b).

\subsection{Imposex biomarker for organotin presence in aquatic systems}

The induction of the imposex in Babylonia formosae habei by organotin contamination was studied by Shi et al. (2003) in several aquatic locations in China. B. formosae habei is an ideal biomarker candidate as it is widespread in distribution, has easily identifiable imposex characteristics, and has large degrees of variations in imposex development. High imposex percentages, over 95\%, were observed in B. formosae habei in the Daya estuarine, the Haimen estuarine, and the Guangao estuarine along with the coastlines of Guangdong province (Shi et al., 2003).

Despite finding low TBT levels (less than $1 \mathrm{ng} / \mathrm{L}$ ) in 10 of 33 water samples, imposex of marine gastropods was widespread (Huang et al., 2005). Females of T. clavigera, Thais distinguenda, Cantharus cecillei, Nassarius hepaticus, Nassarius siquijorensis, Chicoreus asianus, Chicoreus brunneus and Morula margariticola collected from Xiamen, Shantou and Huiyang estuaries were observed to have imposex percentages ranging from 90 to $100 \%$ (Huang et al., 2005). More detailed studies of the various stages and types of imposex of gastropods were conducted and resulted in identifying seven stages (SO-S6) of morphological manifestations of imposex. Imposex was observed in 30 species from 8 families of 
gastropods collected from coastal waters of mainland China. This was the first time imposex characteristics were found in 20 of these species (Shi et al., 2005). The coastlines around Dalian, Lianyungang, Xiamen, Shenzhen, the Pearl River, Beihai, Haikou and Dongya were observed to have high percentages of sterile individuals (10-27\%) with the highest incidences of female sterility found along the coast between Shantou and Shenzhen (Shi et al., 2005). Common measurements used to describe the extent of imposex include the Vas Deferens Sequence Index (VDSI) and Relative Penis Sequence Index (RPSI) (Gibbs et al., 1987). The VDSI for $B$. formosae habei was found to be related to TBT concentrations along the southern Chinese coastlines (VDSI of 4 at $1.19 \mathrm{ng} / \mathrm{L}$ TBT and VDSI of 5 at $3.35 \mathrm{ng} / \mathrm{L}$ TBT) (Shi et al., 2005). These results highlight that imposex of gastropods is widespread and severe along the studied coastlines of China and necessitate future research on understanding its causes and correlating it to organotin pollution.

In TBT-contaminated areas in Hong Kong, imposex development in T. clavigera has been observed. In Victoria Harbor and Aberdeen, $92 \%$ of females were observed to be effectively sterilized because of imposex (Blackmore, 2000.). A recent determination of the imposex status, sex ratios, and tissue burdens of organotin compounds in T. clavigera and Thais luteostoma from 29 coastal sites was conducted by Leung et al. (2006). Organotin contamination resulted in a male-biased population. Imposex had occurred in all specimens, with VDSI and RPSI ranging from 2.38 to 5.36 and 0.06 to 64.22 , respectively, for T. clavigera and from 2.92 to 5.31 and 0.17 to 23.44 , respectively, for T. luteostoma (Leung et al., 2006). In efforts to develop the best criteria to describe imposex, VDSI has been observed to be a better indicator for the relative intensity of imposex in $T$. clavigera as it does not vary with seasonal variations like the RPSI (Li, 2005). In general, the imposex characteristic of $T$. clavigera, widely distributed along Chinese coastlines, is easy to identify and therefore, a promising biomarker for organotin contamination research in China.

Hung et al. (2001) predicted that DBT, MBT and TPT had little or no effect on the development of imposex in rock shells ( $T$. clavigera) in Taiwan. Imposex development in these organisms varied largely with seasonal changes. For example, in oyster mariculture sites in Taiwan, oysters had lower imposex percentages in the summer (54\%) than in the winter (93\%).

Biomarker research using imposex of gastropods to indicate organotin presence is challenging as very little is known about the imposex mechanism. Current research focuses on species that are easily obtained, causing more difficult to collect species to be overlooked as biomarkers. Successes with biomarker organisms are often limited to the area of collection and have limited applications in different locations with different contamination history (Shi and Huang, 2001). Currently, research is in its preliminary stages and much more is needed to develop and extend the use of biomarkers for effective organotin monitoring.

\section{Conclusion}

From reviewing published literatures describing organotin concentrations in the waters, sediments and foods, organotin contamination is a large problem in China. This review gives the first description of the overall severity and distribution of organotin pollution throughout China. In general, organotin research has focused on understanding butyltin concentrations in different environmental media in China. Butyltin contamination is serious in locations with high shipping activity. Our review has shown that butyltin contamination is not limited to water but also to the biota within these ecosystems and to the food supplied from these locations. Furthermore, butyltin can be accumulated in sediments, creating a long-term source of dangerous degradation products. As demands for organotin use in industrial application increase, their adverse effects to ecosystems and humans will also become more dangerous. A better understanding of how organotins behave in the environment and its ecotoxicology is necessary to prevent future damages. The present review demonstrates a critical need for regulations restricting the input sources of organotins in China.

\section{Acknowledgements}

This work was jointly supported by the State High Tech Development Plan (2006AA06Z424), the National Natural Science Foundation of China $(40503014,20621703)$, and the Chinese Academy of Sciences (KZCX2-YW-420-21). The authors would also like to express their sincere thanks to Adina Chuang for her invaluable comments and constructive suggestions on the paper.

\section{References}

Belfroid, A.C., Purperhart, M., Ariese, F., 2000. Organotin levels in seafood. Marine Pollution Bulletin 40, 226-232.

Blackmore, G., 2000. Imposex in Thais clavigera (neogastropoda) as an indicator of TBT (tributyltin) bioavailability in coastal waters of Hong Kong. The Journal of Molluscan Studies 66, 1-8.

Bryan, G.W., Gibbs, P.E., 1991. Impact of low concentrations of tributyltin (TBT) on marine organisms: a review. In: Newman, M.C., McIntosh, A.W. (Eds.), Metal Ecotoxicology: Concepts and Applications. Lewis, Boca Raton, FL, pp. 323-361.

Bryan, G.W., Gibbs, P.E., Burt, G.R. 1988. A comparison of the effectiveness of tri- $n$ butyltin chloride and five other organotin compounds in promoting the development of imposex in the dog-whelk, Nucella lapillus. Journal of the Marine Biological Association of the United Kingdom 68, 733-744.

Bryan, G.W., Gibbs, P.E., Burt, G.R., Hummerstone, L.G., 1987. The effects of tributyltin accumulation on adult dog-whelks, Nucella lapillus: long-term field and laboratory experiments. Journal of the Marine Biological Association of the United Kingdom 67, 524-544.

Chau, K.W., 2005. Characterization of transboundary POP contamination in aquatic ecosystems of Pearl River delta. Marine Pollution Bulletin 51, 960-965.

Chau, Y.K., Maguire, R.J., Brown, M., Yang, F., Batchelor, S.P., 1997. Occurrence of organotin compounds in the Canadian aquatic environment five years after the regulation of antifouling uses of tributyltin. Water Pollution Research Journal of Canada 32, 453-521

Cleary, J.J., 1985. Organotin and total tin in coastal waters of South-west England. Marine Pollution Bulletin 16, 350-355

Dong, C.D., Chen, C.W., Liu, L.L., 2004. Seasonal variation in the composition and concentration of butyltin compounds in marine fish of Taiwan. Environmental Pollution 131, 509-514.

Dowson, P.H., Bubb, J.M., Lester, J.N., 1993. A study of the partitioning and sorptive behavior of butyltins in the aquatic environment. Applied Organometallic Chemistry 7, 623-633.

EPA-822-B-02-001, 2002. Ambient Aquatic Life Water Quality Criteria for Tributyltin (TBT)-draft. United States Environmental Protection Agency, Office of Water 4304T, Washington, DC, USA.

European Union, 2003. European Union Scientific Cooperation Report. (available from: http://europa.eu.int/comm/food/food/chemicalsafety/contaminants/ index_en.htm).

Fent, K., 1996. Ecotoxicology of organotin compounds. Critical Reviews in Toxicology 26 (1), 1-117.

Fu, J.M., Mai, B.X., Sheng, G.Y., Zhang, G., Wang, X.M., Peng, P.A., Xiao, X.M., Ran, R., Cheng, F.Z., Peng, X.Z., Wang, Z.S., Tang, U.W., 2003. Persistent organic pollutants in environment of the Pearl River delta, China: an overview. Chemosphere $52,1411-1422$.

Gao, J.M., Hu, J.Y., Wan, Y., An, W., An, L., Zheng, Z.G., 2004. Butyltin compounds distribution in the coastal waters of Bohai Bay, People's Republic of China. Bulletin of Environmental Contamination and Toxicology 72, 945-953.

Gao, J.M., Hu, J.Y., Zhen, H., Yang, M., Li, B.Z., 2006. Organotin compounds in the Three Gorges Reservoir region of the Yangtze River. Bulletin of Environmental Contamination and Toxicology 76, 155-162.

Gibbs, P.E., Bryan, G.W., 1986. Reproductive failure in populations of the dogwhelk, Nucella lapillus, caused by imposex induced by tributyltin from antifouling paints. Journal of the Marine Biological Association of the United Kingdom 66, 767-777.

Gibbs, P.E., Bryan, G.W., Pascoe, P.L., Burt, G.R., 1987. Reproductive failure in populations of the dogwhelk, Nucella lapillus, caused by imposex induced by tributyltin from antifouling paints. Journal of the Marine Biological Association of the United Kingdom 67, 507-523.

Gibbs, P.E., Pascoe, P.L., Burt, G.R., 1988. Sex change in the female dog-whelk, Nzwella lapillus, induced by TBT from anti-fouling paints. Journal of the Marine Biological Association of the United Kingdom 68, 715-731.

Gibbs, P.E., Bryan, G.W., 1996. TBT-induced imposex in neogastropos snail: masculinization to mass extinction. In: de Mora, S.J. (Ed.), Tributyltin: Case Study of an Environmental Contaminant. Cambridge University Press, Cambridge, UK, pp. 212-276. 
Harino, H., Fukushima, M., Yamamoto, Y., Kawai, S., Miyazaki, N., 1998. Contamination of butyltin and phenyltin compounds in marine environment of Otsuchi Bay, Japan. Environmental Pollution 101, 209-214.

Hoeh, M., 2001. Organotin compounds in the environment an overview. Applied Geochemistry 16, 719-743.

Hu, J.Y., Zhen, H.J., Wan, Y., Gao, J.M., An, W., An, L.H., Jin, F., Jin, X.H., 2006. Trophic magnification of triphenyltin in a marine food web of Bohai Bay, North China: comparison to tributyltin. Environmental Science and Technology 40 (10), 3142-3147.

Huang, C.J., Dong, Q.X., Lie, Z., Wang, Z.X., Zhou, K., 2005. An investigation of organotin compound contamination in three harbors along southeast coast of China. Acta Oceanlogica Sinica 27 (1), 57-63 (in Chinese).

Huang, G.L., Bai, Z.P., Dai, S.G., Xie, Q.L., 1993. Accumulation and toxic effect of organometallic compounds on algae. Applied Organometallic Chemistry 7 (6), 373-380.

Hung, T.C., Hsu, W.K., Mang, P.J., Chuang, A., 2001. Organotins and imposex in the rock shell, Thais clavigera, from oyster mariculture areas in Taiwan. Environmental Pollution 112, 145-152.

Hung, T.C., Lee, T.Y., Liao, T.F., 1998. Determination of butyltins and phenyltins in oysters and fishes from Taiwan coastal waters. Environmental Pollution 102 (2-3), 197-203.

Jiang, G.B., Zhou, Q.F., 2000. Direct Grignard phenylation of organotins-contaminated lard samples followed by capillary gas chromatography with flame photometric detection. Journal of Chromatography A 886, 197-205.

Jiang, G.B., Liu, J.Y., Zhou, Q.F., 2004. Search for the contamination source of butyltin compounds in wine: agglomerated Cork stoppers. Environmental Science and Technology 38, 4349-4352.

Jiang, G.B., Zhou, Q.F., He, B., 2000. Speciation of organotin compounds, total tin, and major trace metal elements in poisoned human organs by gas chromatography-flame photometric detector and inductively coupled plasma-mass spectrometry. Environmental Science and Technology 34, 2697-2702.

Jiang, G.B., Zhou, Q.F., Liu, J.Y., Wu, D.J., 2001. Occurrence of butyltin compounds in the waters of selected lakes, rivers and coastal environments from China. Environmental Pollution 115, 81-87.

Kannan, K., Corsolini, S., Focardi, S., Tanabe, S., Tatsukawa, R., 1996. Accumulation pattern of butyltin compounds in dolphin, tuna, and shark collected from Italian coastal waters. Archives of Environmental Contamination and Toxicology 31,19-23.

Kannan, K., Falandysz, J., 1997. Butyltin residues in sediments, fish, fish-eating birds, harbor porpoise and human tissues from the polish coast of the Baltic Sea. Marine Pollution Bulletin 34, 203-207.

Kannan, K., Senthilkumar, K., Elliott, J.E., Feyk, L.A., Giesy, J.P., 1998. Occurrence of butyltin compounds in tissues of water birds and seaducks from the United States and Canada. Archives of Environmental Contamination and Toxicology 35, 64-69.

Lau, M.M., 1991. Tributyltin antifoulings: a threat to the Hong Kong marine environment. Archives of Environmental Contamination and Toxicology 20, 299-304.

Layman, P.L., 1995. Marine coating industry adopts new technology for shifting markets. Chemical and Engineering News 5 (1), 23-25.

Leung, K.M.Y., Kwong, R.P.Y., Ng, W.C., Horiguchi, T., Qiu, J.W., Yang, R.Q., Song, M.Y., Jiang, G.B., Zheng, G.J., Lam, P.K.S., 2006. Ecological risk assessments of endocrine disrupting organotin compounds using marine neogastropods in Hong Kong. Chemosphere 65, 922-938.

Li, Z.Y., 2005. Seasonal variation in imposex intensity of Thais clavigera. Chinese Journal of Oceanology and Limnology 23 (2), 163-168.

Li, Z.Y., Zhou, Q.F., Jiang, G.B., Liu, G.G., 2003. The present situation of butyltin compounds contamination in marine products in several Chinese cities. China Environmental Science 23 (2), 144-147 (in Chinese).

Liu, J.M., Jiang, G.B., Liu, J.Y., Zhou, Q.F., Yao, Z.W., 2003. Evaluation of methyltin and butyltin pollution in Beijing Guanting reservoir and its downriver Yongding river. Bulletin of Environmental Contamination and Toxicology 70, 219-225.

Liu, J.Y., Jiang, G.B., 2001. Determination of butyltin compounds in sediments by headspace solid phase microextraction and capillary gas chromatography with flame photometric detector using quartz surface-induced luminescence. Chinese Journal of Analytical Chemistry 29 (2), 158-160 (in Chinese).

Liu, J.Y., Jiang, G.B., 2002. Survey on the presence of butyltin compounds in Chinese alcoholic beverages, determined by using headspace solid-phase microextraction coupled with gas chromatography-flame photometric detection. Journal of Agriculture and Food Chemistry 50, 6683-6687.

Liu, J.Y., Jiang, G.B., Xu, D.M., 2002. Analysis of butyltin compounds in seawater samples collected from areas nearby the Greatwall Station in Antarctic and the South of Taiwan. Acta Scientiae Circumstantiae 22 (2), 267-269 (in Chinese).

Matthiessen, P., Reynoldson, T., Billinghurst, Z., Brassard, D.W., Cameron, P., Chandler, G.T., Davis, I.M., Horiguchi, T., Mount, D.R., Oehlmann, J., Pottinger, T.G., Sibley, P.K., Thompsom, H.M., Vethaak, A.D., 1999. Field assessment of endocrine disruption in invertebrates. In: de Fur, P.L., Crane, M., Ingersoll, C., Tattersfield, L. (Eds.), Endocrine Disruption in Invertebrates: Endocrinology Testing and Assessment. SETAC Press, Pensacola, FL, pp. 199-270.

Matthiessen, P., Gibbs, P.E., 1998. Critical appraisal of the evidence for tributyltinmediated endocrine disruption in mollusks. Environmental Toxicology and Chemistry 17, 37-43.

Morton, B., Blackmore, G., 2001. South China sea. Marine Pollution Bulletin 42 (12), 1236-1263.

Penninks, A.H., 1993. The evaluation of data-derived safety factors for bis(tri-nbutyltin)oxide. Food Additives and Contamination 10, 351-361.
Rüdel, H., Lepper, P., Steinhanses, J., 2003. Retrospective monitoring of organotin compounds in marine biota from 1985 to 1999: results from the German Environmental Specimen Bank. Environmental Science and Technology 37, 1731-1738.

Seinen, W., Helder, T., Vernij, H., Penninks, A., Leeuwangh, P., 1981. Short term toxicity of tri- $n$-butyltin chloride in rainbow trout (salmo gairdneri Richardson) yolk sac fry. Science of the Total Environment 19, 155-166.

Shi, H.H., Huang, C.J., 2001. Tributyltin (TBT) pollution and imposex in marine gastropod. Acta Ecologica Sinica 21 (10), 1711-1717 (in Chinese).

Shi, H.H., Huang, C.J., Lei, Z., 2003. Organotin compound pollution in coastal water as indicated by imposex in babylonia formosae habei. Ocean Technology 22 (1), 82-86 (in Chinese).

Shi, H.H., Huang, C.J., Zhu, S.X., Yu, X.J., Xie, W.Y., 2005. Generalized system of imposex and reproductive failure in female gastropods of coastal waters of mainland China. Marine ecology Progress Series 304, 179-189.

Short, J.W., Sharp, J.L., 1989. Tributyltin in bay mussels (Mytilus edulis) of the Pacific coast of the United States. Environmental Science and Technology 23, 740-743.

Smith, B.S., 1971. Sexuality in the American mud snail, Nassarius obsoletus Say. Proceedings of the Malacological Society of London 39, 377-378.

Smith, B.S., 1981a. Reproductive anomalies in stenoglossan snails related to pollution from marinas. Journal of Applied Toxicology 1, 15-21.

Smith, B.S., 1981b. Male characteristics on female mud snails caused by antifouling bottom paints. Journal of Applied Toxicology 1, 22-25.

Smith, B.S., 1981c. Tributyltin compounds induce male characteristics on female mud snails Nassarius obsoletus = Ilayanassa obsoleta. Journal of Applied Toxicology 1, 141-144.

Stäb, J.A., Traas, T.P., Stroomberg, G., Van Kesteren, J., Leonards, P., Van Hattum, B. Brinkman, U.A.T., Cofino, W.P., 1996. Determination of organotin compounds in the foodweb of a shallow freshwater lake in the Netherlands. Archives of Environmental Contamination and Toxicology 31, 319-328.

Sudaryanto, A., Takahashi, S., Monirith, I., Ismail, A., Muchtar, M., Zheng, J.S. Richardson, B.J., Subramanian, A., Prudente, M., Hue, N.D., Tanabe, S., 2002. Asia-Pacific mussel watch: monitoring of butyltin contamination in coastal waters of Asian developing countries. Environmental Toxicology and Chemistry 21 (10), 2119-2130.

Sun, H.W., Dai, S.G., Huang, G.L., 2005. Advances in research of organotin compounds in environment. In: Dai, S.G. (Ed.), Advances in Environmental Chemistry. Chemical Industry Press, Beijing, pp. 247-263 (in Chinese).

Takahashi, S., Tanabe, S., Takeuchi, I., Miyazaki, N., 1999. Distribution and specific bioaccumulation of butyltin compounds in a marine ecosystem. Archives of Environmental Contamination and Toxicology 37 (1), 50-61.

Tanabe, S., 1999. Butyltin contamination in marine mammals - a review. Marine Pollution Bulletin 39, 62-72.

Tanabe, S., Prudente, M., Mizuno, T., Hasegawa, J., Iwata, H., Miyazaki, N., 1998. Butyltin contamination in marine mammals from north Pacific and Asian coastal waters. Environmental Science and Technology 32, 193-198.

Unger, M.A., Macintyre, W.C., Huggett, R.J., 1988. Sorption behavior of tributyltin on estuarine and fresh water sediments. Environmental Toxicology and Chemistry 7, 907-915

Warren, T.P., 1973. Organotin compounds: industrial applications and biologica investigation. Environmental Health Perspectives 6, 61-79.

World Health Organization, 1990. Tributyltin compounds. WHO, Geneva, p 273.

Yang, R.Q., Zhou, Q.F., Jiang, G.B., 2006a. Butyltin accumulation in the marine clam Mya arenaria: an evaluation of its suitability for monitoring butyltin pollution. Chemosphere 63, 1-8.

Yang, R.Q., Zhou, Q.F., Liu, J.Y., Jiang, G.B., 2006b. Butyltins compounds in molluscs from Chinese Bohai coastal waters. Food Chemistry 97, 637-643.

Yang, R.Q., Zhou, Q.F., Zhang, Q.H., Jiang, G.B., 2006c. Study on the contamination status of butyltins in Taihu lake. Environmental Science 27 (4), 661-664 (in Chinese).

Yang, X.L., Yang, R.Q., Jiang, G.B., 2006d. Using mytilus edulis and pema viridis as bioindicators to monitor butyltins pollution along the Bohai coastal sites. Environmental Chemistry 25 (1), 88-91 (in Chinese).

Yuan, D.X., Yang, D.N., Wade, T.L., Qian, Y.R., 2001. Status of persistent organic pollutants in the sediment from several estuaries in China. Environmental Pollution 114, 101-111.

Zhang, G., Van, J., Fu, J.M., Parker, A., Li, X.D., Wang, Z.S., 2003. Butyltins in sediments and biota from the Pearl river delta, South China. Chemical speciation and bioavailability $14,35-42$.

Zhang, S.H., 2001. Analysis of adverse effects of TBT and its control measures. Environmental Protection in Transportation 22 (3), 30-33 (in Chinese).

Zhou, M.J., Li, Z.Y., Yan, T., Li, J., 1994. Organotin in marine environment and its effect on marine organisms. Progress in Environmental Science 2, 67-76 (in Chinese).

Zhou, Q.F., Jiang, G.B., Li, Z.Y., Liang, L.N., Yuan, C.G., Wu, Y.N., 2004. Survey of butyltin compounds in 12 types of foods collected in China. Food Additives and Contaminants 21 (12), 1162-1167.

Zhou, Q.F., Jiang, G.B., Liu, J.Y., 2001. Small-scale survey on the contamination status of butyltin compounds in seafoods collected from seven Chinese cities. Journal of Agriculture and Food Chemistry 49, 4287-4291.

Zhou, Q.F., Jiang, G.B., Liu, J.Y., 2002. Organotin pollution in China. The Scientific World Journal 2, 655-659.

Zhou, Q.F., Li, Z.Y., Jiang, G.B., Yang, R.Q., 2003. Preliminary investigation of a sensitive biomarker of organotin pollution in Chinese coastal aquatic environment and marine organisms. Environmental Pollution 125, 301-304. 